\title{
The representation of the temporal notion of post-colonial Africa in South African history textbooks
}

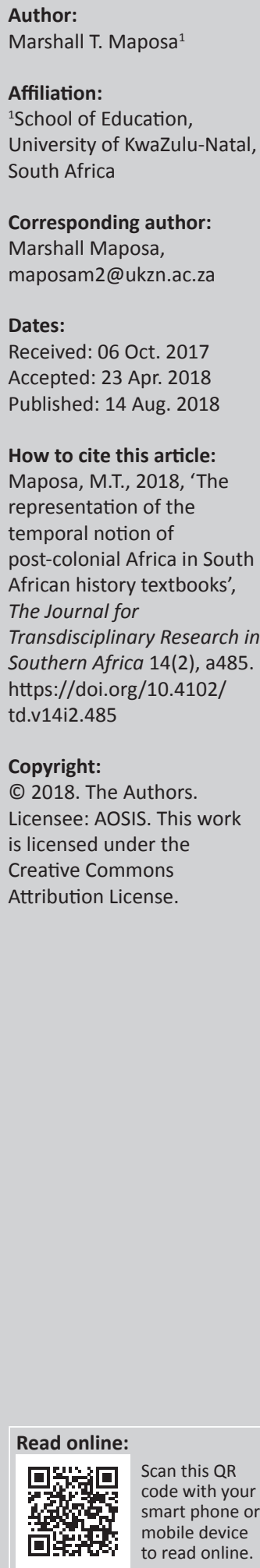

\begin{abstract}
This article is premised on the current (2015-2016) developments in South Africa whereby the country's youth are increasingly engaging in discourses of South Africa's post-colonial condition and the need for decolonisation. But how do the history textbooks that they use in schools construct this contentious post-colonial period? On this basis, the main objective is to examine the temporal representation of post-colonial Africa in South African history textbooks. Critical discourse analysis was applied on a sample of four National Curriculum Statementaligned textbooks with a focus on sections that covered content on post-colonial Africa. The findings from the textual analysis show that the temporal notion of post-colonial Africa is not clearly framed within a particular period. The ambiguity of the temporal notion, a fundamental concept in history, stems from the fact that the lexicalisations used as time markers in the textbooks cannot be linked to one particular date, resulting in a post-colonial Africa whose beginning and - more specifically - end cannot be unambiguously determined. The textbooks also sometimes refer to the post-colonial period as singular, whereas in other cases they describe the period as consisting of different phases. I conclude that such ambiguity reveals a loophole in educating the learners about a period whose circumstances they are trying to not only engage but also transform.
\end{abstract}

\section{Introduction}

Just over 20 years after the end of apartheid, there is evidence of an increase in the discourses of decolonisation of education in South Africa. The decolonisation discourses have constructed South Africa as not only post-apartheid but also post-colonial, thus reigniting the post-colonial discourses that have taken place in other African countries (Luckett 2016; Mamdani 2011; Mbembe n.d.). At the heart of the decolonisation project in Africa is the experience of Western colonisation, which had taken hold of the continent by the beginning of the 19th century. Further to that is the assumption that political colonisation ended, yet it still is to be matched with an end to other forms of colonisation (Rahaman, Yeazdani \& Mahmud 2017). It is because of political decolonisation that Africa is assumed to be in the post-colonial era. However, as Shohat (1992) notes, " post-colonial" renders a problematic temporality' (p. 103). Two questions that can be asked in this regard are as follows: When did the post-colonial period start?; and When did it or will it end? As Young (2004) states, 'the question arises whether "post-colonial" remains a serviceable designation' (p. 24).

If South Africa is to be constructed as post-colonial, then there is a need to engage with this concept. It would be expected that the education that South Africans experienced post-1994 should help them gain a good understanding of such concepts. One of the ways of finding out is analysing history textbooks, which tend to be purveyors of officially sanctioned knowledge that should help the users to gain a particular consciousness (Foster \& Crawford 2006). This article is drawn from a bigger research project whose findings show that post-colonial Africa is represented in South African history textbooks in the form of four notions: the temporal, spatial, humanised and experiential notions (Maposa 2014). I will focus on only the temporal notion, which I have identified to be crucial in understanding whether South Africa and the rest of Africa are postcolonial. In fact, historical time is a key concept in historical understanding as 'historical evidence itself derives its meaning from the time frame in which it is set' (Stow \& Haydn 2012:85). This means that the temporal notion in history provides a framework for understanding the topic under study. Likewise, the understanding drawn from this study can provide another platform on which debates on the decolonisation project in South Africa can be based.

Therefore, the purpose of this article is to understand how South African history textbooks construct this contentious post-colonial period for their users. The article will reveal the ambiguities in terms 
of the meanings of post-colonial Africa across the analysed textbooks, which could lead to a lack of clarity of the textbook users' conceptualisation of the period they are not only part of, but also are possibly actively trying to influence. In order to come to such conclusions, I start by reviewing literature on the contestations of the post-colonial after which I will explain the theoretical foundations of the study. This will be followed by an explanation of the methodology, after which the findings are described, interpreted and explained. The article ends with a conclusion that explains the implications of the study.

\section{Conceptual contestations on the post-colonial}

It is important to start by clarifying how this article distinguishes post-colonial from postcolonial. As St-Pierre (1997) argues:

Still other distinctions would have to be made. Between 'postcolonial' with a hyphen, and 'postcolonial' without, for example.

... Hulme and Iversen use the first 'as a temporal marker' and the second 'to indicate the analytical concept of greater range and ambition, as in "postcolonial theory"'. (p. 11)

For the sake of conceptual clarity, in this article I use 'postcolonial' to refer to the temporal marker, whereas 'postcolonial' refers to the analytical concept or theory. The latter will be expounded in the next section on theoretical considerations.

One of the contentions over the use of the term 'postcolonial' as a temporal marker concerns the overlap of the colonial and the post-colonial. To explain this overlap, StPierre (1997) uses the example of South Africa where at least three possible dates have been suggested as temporal markers for the beginning of the post-colonial era. The first is 1931 when the British government granted South Africa dominion status via the 1931 Statute of Westminster (1937), and the second is 1961 when South Africa became a republic. The third date is 1994, as post-colonial theorists such as Said (1978) and McClintock (1993) argue that apartheid was, in fact, a form of colonisation. Said equates apartheid South Africa to Palestine by labelling the then oppressed to be victims of victims, whereas McClintock (1993) contends that there are two forms of colonisation: internal colonisation, whereby people are oppressed by a dominant group within the same country, and imperial colonisation, for example when European powers colonised territories in Africa, Asia and the Americas.

Holistically looking at Africa, there are no uniform dates for the beginning and the end of the colonial period. It is therefore folly to view history as divided into neat eras of pre-colonial, colonial and post-colonial. This is what Shohat (1992) decries to as 'a collapsing of diverse chronologies'. The quotation below elucidates his argument:

Colonial-settler states, such as those found in the Americas, Australia, New Zealand, and South Africa, gained their independence, for the most part, in the eighteenth and nineteenth centuries. Most countries in Africa and Asia, in contrast, gained independence in the twentieth century, some in the nineteen thirties (Iraq), others in the nineteen forties (India, Lebanon), and still others in the nineteen sixties (Algeria, Senegal) and the nineteen seventies (Angola, Mozambique), while others have yet to achieve it. When exactly, then, does the 'post-colonial' begin? (p. 103)

The above quotation implies that the identification of the postcolonial hinges heavily on the identity of the subject under focus. Related to this point are the contentions over who experiences post-coloniality and who does not. For example, do the former colonisers themselves not become post-colonial too (St-Pierre 1997)? This line of reasoning implies that the effects of decolonisation are not limited to the formerly colonised only. Yet, most post-colonial studies focus on what Said (1978) refers to as the subaltern (the formerly colonised). In fact, post-colonial studies are alternatively often referred to as subaltern studies. Nonetheless, Tosh (2009) maintains that the empire cannot be divorced from the metropole as both parties influenced each other, no matter how skewed the colonial relationship was. This view implies that the former Western colonial powers are also in a post-colonial era.

In critique of the foregoing argument, McClintock (1993) contends that postcolonialism fails to show the differences between 'the beneficiaries of colonialism (generally the excolonisers) and the casualties of colonialism (generally the excolonised)' (p. 86). In simple terms, everyone can claim to be 'living in a "post-colonial epoch"' (Shohat 1992:103). However, St-Pierre (1997) insists that postcolonialism is a polite way of referring to neo-colonialism, which in turn cannot exist in the absence of anti-colonial struggles. In other words, those who are not involved in anti-colonial struggles cannot claim to be either post-colonial or to be in a post-colonial condition. Such a view is more problematic if one tries to apply it to McClintock's (1993) internal colonisation, because it implies that in countries like South Africa, one part of the present population is post-colonial while another is not.

Not much alternatives to the use of the term 'post-colonial' are suggested in literature. Worth noting is Young's (2004) argument that the term only emerged in the 1980s and before African countries tended to refer to themselves as 'postindependence'. Shohat (1992) suggests the continued use of post-independence on the basis that it 'attribut[es] power to the nation-state [and] it also makes Third World regimes accountable' (p. 107). However, critiques can also be conducted on the use of post-independence, but they do not fall under the scope of this article (Young 2004).

The complications discussed above are testimony to the contested ground on which post-colonial studies find themselves. It is for this reason that Tosh (2009) argues that the temporal notion of the post-colonial can only be applied just as a convenient, but superficial chronological marker.

\section{Post-colonial theory and history textbooks}

History textbooks are usually not divorced from the discourses permeating through society as official history. 
These discourses become educational discourse which learners are exposed to as they use the textbooks (Naseem 2008). History textbooks are therefore 'a device for conveying intellectual ideas' (Kojanitz 2008:214). This means that history textbooks contain much more than historical content, but they also have underlying ideologies that they expose their users to. Hence, they can, in the case of this study, provide an understanding of post-colonial societies and individuals. This understanding can be enhanced by analysing the textbooks through the lens of postcolonialism.

The major contributors in the field of postcolonialism include Fanon (1961), Said (1978), Spivak (1993) and Bhabha (1994). They use this theory fundamentally to understand the nature of post-colonial societies, and this is applicable in this study's attempt to analyse representations of post-colonial Africa. As with most theories, postcolonialism has varying constructions and contestations. Hitchcock (1997) claims that amongst a plethora of postcolonialisms, three are outstanding: experiential postcolonialism, materialist postcolonialism and discursive postcolonialism. In the interest of space, I will not elaborate on the first two because they are not of direct relevance to this study. Suffice to say, experiential postcolonialism is 'firmly grounded in the wake of the great decolonization movements ... and that encompasses both works of theory and a huge body of heterogeneous culture' (Hitchcock 1997:233). This type of postcolonialism is useful in attempts to understand the experiences and narratives that relate to post-colonial societies. Materialist postcolonialism consists of 'theoretical approaches that seek to understand the relationship between the experience of postcoloniality and the socioeconomic restructuring of the globe' (Hitchcock 1997:233). Postcoloniality here refers to the state that post-colonial societies find themselves in. Materialist postcolonialism can therefore be used as an analytic tool to understand how the state of such societies is determined not just by the said societies but also by broader international configurations. The uniqueness of discursive postcolonialism is in that it 'assesses the condition of postcoloniality as a discursive construction' (Hitchcock 1997:233). I used discursive postcolonialism as a lens in this study to analyse the history textbooks for postcoloniality because it foregrounds issues of discourse crucial to understanding postcolonialism.

Discourse analyses grew out of what is commonly referred to as the linguistic turn, whose basic premise is that there cannot be any meaning in the absence of language (Dimitriadis \& Kamberelis 2006). It implies the importance of language in the construction of any meaning. Indeed, scholars such as Foster and Crawford (2006) and Firer (1998) acknowledge the constructive power of language in history textbooks. This would similarly imply that from a discursive post-colonial point of view, post-colonial Africa is not only constructed by language, but it can be understood through language. However, language also gets meaning though situational and institutional context (Ifversen 2003).

The phenomena can be represented as subjects and objects. Nevertheless, subjects and objects are never fully meaningful in the sense that they only get meaning from the interpretations of their representations. As a result, they can be referred to as 'empty signifiers' because they do not necessarily have meaning until society gives it to them (Howarth \& Stavrakakis 2000:8). Discourse theory explains how objects and subjects can be changed from empty signifiers to become what society understands them to be. This is a process of 'actualisation', where discourses transform empty signifiers into meaningful realities. According to Dimitriadis and Kamberelis (2006), it is within a particular context that 'various institutions (including schools) produce discourses that then constitute what can be known or practiced relative to that body of knowledge' (p. 112). In the case of education, the dominant discourse is then translated into becoming dominant educational discourses found in history textbooks (Naseem 2008). Ideas are modified into dominant discourses through a process of articulation (Howarth \& Stavrakakis 2000). Therefore, educational media such as history textbooks become tools for the dissemination of the official discourses from above. In fact, the dynamics of textbook production shows that although the state may be dominant, other powerful players, including publishers and advocacy groups, manage to infuse their discourses into the textbooks (Rodden 2009). As Foucault argues, people become 'disciplined subjects' of such discourses (Dimitriadis \& Kamberelis 2006:112). This makes it important to analyse the text in history textbooks in terms of how it helps the textbook users to make meaning of the world they live in.

\section{Critical discourse analysis as a methodology}

As noted in the introduction, this article is drawn from a larger scale study which focused on the analysis of the construction of African consciousness in South African history textbooks. The methodological considerations are explained in detail in another paper (Maposa 2015). For this article, I analysed four history textbooks which I purposively sampled from various publishers. I analysed textbooks that were compliant to the National Curriculum Statement (NCS) - the South African curriculum that ran from 2003 to 2011 when it was replaced by the Curriculum and Assessment Policy Statement (CAPS). This study started when the current or contemporary CAPScompliant textbooks were not yet produced. The CAPS Grade 12 textbooks were only distributed for use in 2014, and by that time, this study was already in its final stages. The sample is represented in Table 1.

Data were generated from only the sections that related to post-colonial Africa. In textbook 1, the relevant section was Chapter 2 titled 'Uhuru' (pp. 53-110). In textbook 2, the data were generated from Chapter 2 titled 'How was Uhuru realised in Africa in the 1960s and 1970s?' (pp. 120-154), whereas textbook 3's relevant theme was in Chapter 2, 'How Uhuru was realised in Africa' (pp. 59-114). In textbook 4, the data were generated from Chapter 2 titled 'How was Uhuru realised in Africa in the 1960s and 1970s?' (pp. 67-114). 
TABLE 1: The research sample.

\begin{tabular}{|c|c|c|c|}
\hline Title & Author(s) & $\begin{array}{c}\text { Date of } \\
\text { publication }\end{array}$ & Publisher \\
\hline $\begin{array}{l}\text { Textbook } 1 \text { (Shuters History } \\
\text { Grade 12) }\end{array}$ & Bartels, J. et al. & 2006 & $\begin{array}{l}\text { Shuter \& } \\
\text { Shooter }\end{array}$ \\
\hline $\begin{array}{l}\text { Textbook } 2 \text { (Making History } \\
\text { Grade 12) }\end{array}$ & Claire, H. et al. & 2007 & Heinemann \\
\hline $\begin{array}{l}\text { Textbook } 3 \text { (Focus on History: } \\
\text { Looking into the Past Grade } 12 \text { ) }\end{array}$ & $\begin{array}{l}\text { Friedman, M. } \\
\text { et al. }\end{array}$ & 2007 & $\begin{array}{l}\text { Maskew Miller } \\
\text { Longman }\end{array}$ \\
\hline $\begin{array}{l}\text { Textbook } 4 \text { (Oxford In Search of } \\
\text { History Grade 12) }\end{array}$ & Bottaro, J. et al. & 2006 & $\begin{array}{l}\text { Oxford } \\
\text { University Press }\end{array}$ \\
\hline
\end{tabular}

My criteria for analysis focused on the author's descriptive text (verbal) and visuals (such as illustrations, photographs or pictures, maps, tables, statistics, graphs and other sources) (Nicholls 2003; Pingel 2010).

I used critical discourse analysis (CDA), a methodology that is not specifically fashioned for history textbook research, but which has contributed to a substantial body of textbook research (Barnard 2003; Lebrun et al. 2002). Critical discourse analysis relates well to issues of language that I explained earlier to be key aspects of discursive postcolonialism. It also involves the consideration of power as a determinant of the knowledge that is sanctioned as truth in the textbooks. For instance, the decision on when South Africa became postcolonial is as much an academic one as it is a power one. Although scholars may debate on which date is appropriate, it is the hegemonic discourse coming from the powerful (not just political) in South Africa that will end up dominating. Therefore, discourses that are in the textbooks are a reflection of the power dynamics at a macro-level of discourse produced by power holders and a micro-level of discourse produced by the average citizens (Van Dijk 2003). What this means is that textbooks are at a meso-level of discourse where the discourses coming from above meet those from below, resulting in the fashioning of a popular discourse or discourses.

Fairclough's (1995) CDA provided a useful framework for analysis through three dimensions: description, interpretation and explanation. My analysis was guided by Janks' (1997) explanation of how Fairclough's CDA can be practically applied. For the descriptive analysis, I selected lexicalisation, which is one of five aspects of functional grammar used in Halliday's (1985) systemic functional linguistics (Janks 1997:335). I also considered the use of particular dates and their alternative lexicalisations and the use of tenses which revealed time frames. I also applied visual semiotics, which consider visuals as signs comprising signifiers that represent a particular meaning (the signified). It is important to note that the visual text in the textbooks makes little reference to time, which can be used to reflect the post-colonial dimension of Africa. By virtue of the nature of visual text, most of the reference to time is either in the captions or in the accompanying verbal text. However, some visuals did exhibit dates of the actual historical activity which then revealed an idea of the time frame for post-colonial Africa that the textbooks represented. The interpretation and explanation relied on literature, theory and the context. In other words, the meanings that I made of the descriptive findings were based on frames of reference guided by literature and the discourses on the context of production (South Africa).

\section{Description, interpretation and explanation of findings}

The findings are divided into three themes: (1) temporal ambiguity stemming from conceptual confusion, (2) a generalised temporal notion of post-colonial Africa and (3) post-colonial Africa as fragmented. These three themes respond directly to the research question on how the temporal notion of post-colonial Africa is represented. The findings from both the verbal and visual text are integrated. This is informed by previous research, which shows that CDA findings make better sense if the meanings from the visual text are understood together with those from the verbal text (Janks 1997; Maposa 2015).

\section{Temporal ambiguity stemming from conceptual confusion}

Although all four textbooks frame post-colonial Africa temporally, only two refer to it explicitly. Post-colonial Africa is lexicalised in textbook 1 as 'Post-independence Africa' (p. 77), whereas textbook 4 refers to the phenomenon as 'independent Africa' (p. 78). In the same regard, textbook 3 uses 'postcolonial' and 'post-independence' interchangeably (p. 102). The same conceptual period is lexicalised in textbook 2 as 'after independence' (p. 49). This reflects a dominant construction of post-colonial Africa in the textbooks as Africa in the period after independence. Nevertheless, as part of this representation, the meaning of independence is not really clarified in any of the textbooks leading to two complications. Firstly, independence seems to be implicitly referring to the concept of Uhuru - a kiSwahili word which means freedom. All the analysed textbooks unambiguously refer to Uhuru as freedom in the verbal text (textbook 1, p. 53; textbook 2, p. 59; textbook 3, p. 49; and textbook 4, p. 68). This then implies a representation of freedom and independence as the same phenomenon and hence a temporal construction of post-colonial Africa as Africa in the period after independence or freedom. This leaves the temporal construction of post-colonial Africa in all the textbooks in a fuzzy and contestable state because the concepts they use as time markers (independence and freedom) are not necessarily one and the same.

The conceptual confusion on a post-colonial dimension for Africa is also evidenced in textbook 1 which has dates of independence for all countries on the map of Africa on page 58 - as shown in Figure 1. However, the map (which excludes the islands surrounding Africa with the exception of Madagascar) creates some complications considering the fact that Liberia, for instance is shown to have gained its independence in 1847, long before virtually the rest of Africa experienced Western colonisation. Other notable dates of independence on the map are for Egypt in 1922 and South Africa in 1961. According to the same map, the last country to gain independence in Africa was Eritrea in 1993. Textbook 3 


\section{MAP 3}

\section{Africa in 1991, showing date of independence}

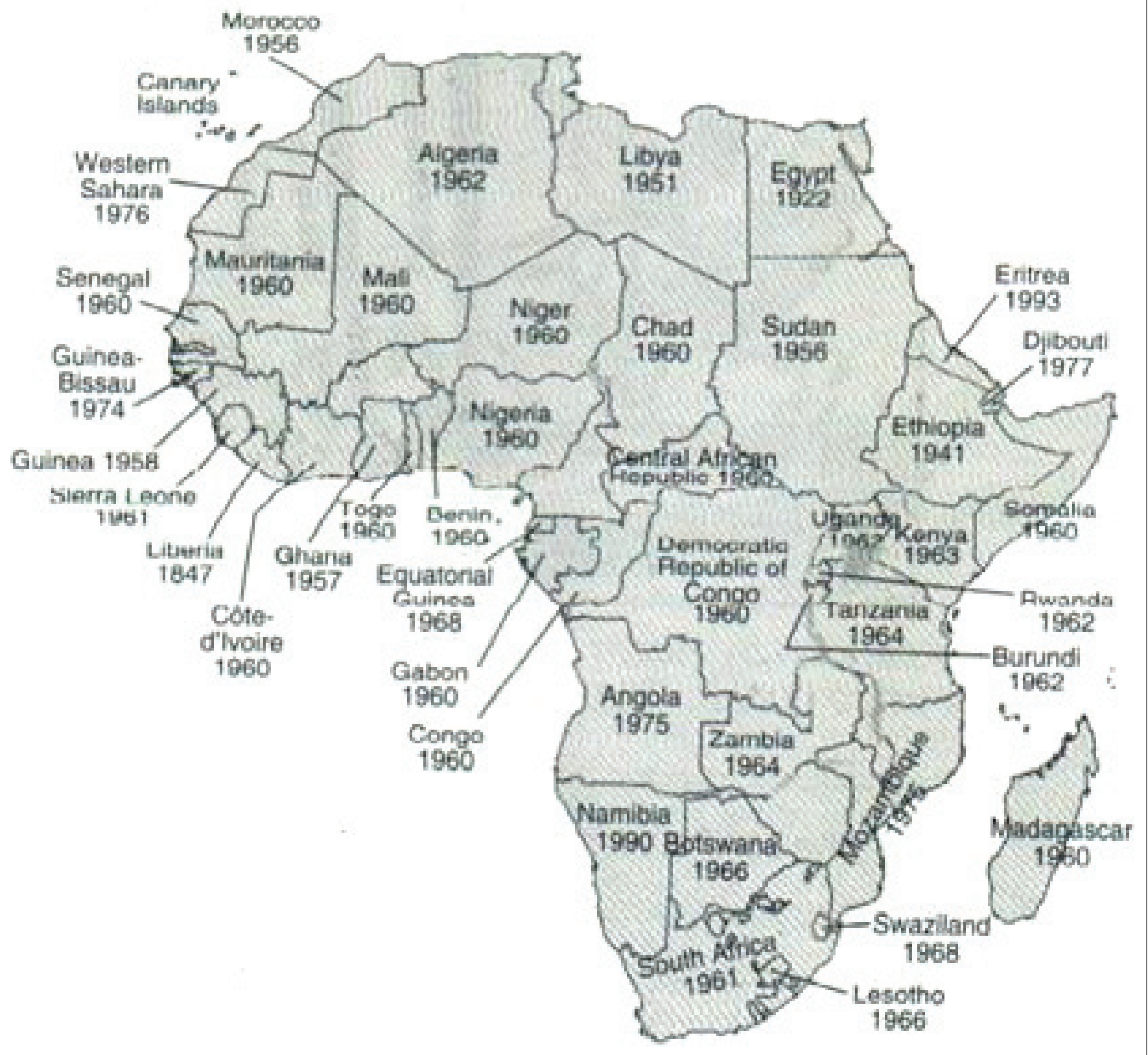

Source: Textbook 1, p. 58

FIGURE 1: Map of Africa.

also has a map with post-colonial dates, but in this case showing changes in governments over the continent containing dates from 1952 in Egypt to 1993 in Eritrea.

The conceptual confusion relates to how independence is not a well-defined concept within the textbooks. The representation in the textbooks clearly defines Uhuru which is alternatively lexicalised as freedom. The use of 'postcolonial' and 'post-independence' interchangeably would imply that the post-colonial period in Africa started with the beginning of independence from Western colonisation. The fact that the textbooks construct Uhuru as freedom and not as independence means that independence and Uhuru are not represented as being similar. The lack of clarity is particularly evident if one considers two factors: that independence for some countries did not necessarily entail freedom; and that some countries, such as Eritrea and later South Sudan, did not necessarily gain their independence from a Western country. This is the crux of the contention over the use of the concept post-colonial with reference to South Africa, for example because dates of independence such as 1961 are not associated with freedom in the country. As a result, the textbooks construct a fuzzy temporal notion of post-colonial Africa whose meaning depends on how concepts are understood. 


\section{A generalised temporal notion of post-colonial Africa}

Another finding from my analysis is that the textbooks fundamentally generalised the post-colonial period in Africa without actually explicitly giving a time frame. In other words, the textbooks refer to the post-colonial era without being specific about its bounding dates. Hence, my analysis referred to dates which were stated with reference to postcolonial events. For example, the paratext of textbook 1 identifies Ghana as the first sub-Saharan African country to gain independence (p. 71). Similarly, the paratext in textbook 4 identifies Namibia as the last country in Africa to gain independence (p. 77). However, textbook 1 and textbook 4 identify the period of Uhuru in Africa to have been in the 1960s and 1970s and extend the post-colonial time frame to the present day. The reason for this extension to the present day is stated in textbook 1: 'many of the issues that challenged and troubled African states in those two decades continue to do so to the present' (textbook 1, p. 53).

An analysis of the textbooks' linguistic choices revealed a similar post-colonial time frame, albeit without explicitly stating so. For example, the constant use of the present perfect tense in textbook 3 shows how the supposed time from independence in Africa to the present day is generalised into one contemporary period. A case in point of the use of the present perfect tense is in the statement: 'From the late 1980s, Africa has witnessed a dramatic shift from single-party states to multiparty political systems' (textbook 3, p. 100). The use of the present perfect tense implies the continuation of an essentially analogous experience from the past to the present. Therefore, the construction in the textbooks is that up to the present day, the post-colonial period has not reached an end yet in Africa.

The dates associated with the visuals in the textbooks also give a rough idea of the generalised time frame for postcolonial Africa. For instance, in textbook 4, the visuals include the Malawian postage stamp of 1964 in Figure 2 (p. 78), the Biafran war in 1969 (p. 102), the women in an Ujamaa village in 1974 (p. 82) and the family fleeing Burundi in 1995 (p. 91). This list of visuals and their dates reveal that the earliest reference to post-colonial Africa in the visual text of textbook 4 is in 1964 and the latest in 1995.

Applying the same analysis criteria to other textbooks, the earliest date related to visual text in textbook 2 is 1960 with reference to the two cartoons of Kwame Nkrumah (pp. 57 and 61) with the latest being from 'the 1980s' when Tanzanians spoke about Ujamaa (p. 53). Similarly, textbook 1 contains statistical tables of gross domestic product (GDP), agricultural production and industrial growth in Tanzania, Kenya, Ghana and Cote d'Ivoire from 1960 to 1987 (textbook 1, p. 97). The textbook also presents graphs indicating trends in population growth and urbanisation, with the $x$-axis starting in 1950. As was shown in Figure 3, the time frame ends with a projection up to 2054.

Therefore, the visual text in the selected textbooks does not construct a uniform temporal dimension for post-colonial

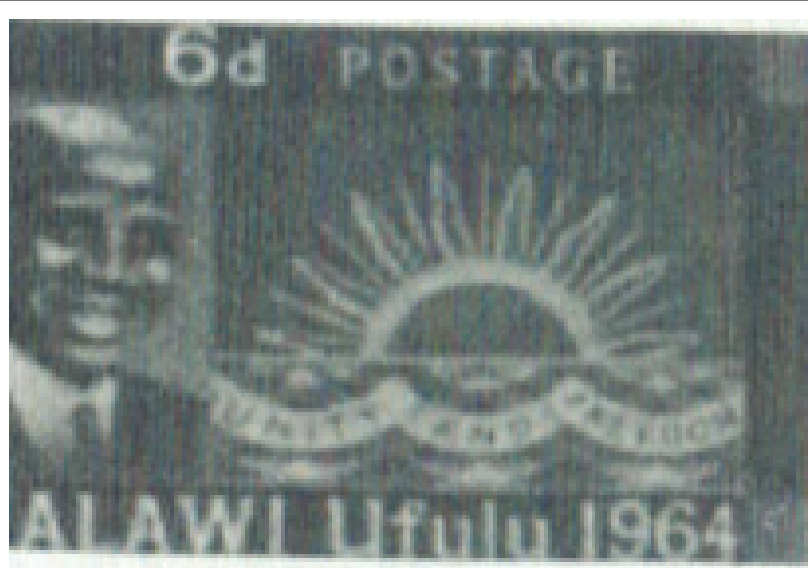

\section{A A Malawian stamp celebrating independence in 1964. Notice the emphasis on 'unity' and 'freedom'.}

Source: Textbook 4, p. 78

FIGURE 2: A Malawian postage stamp showing the date 1964.

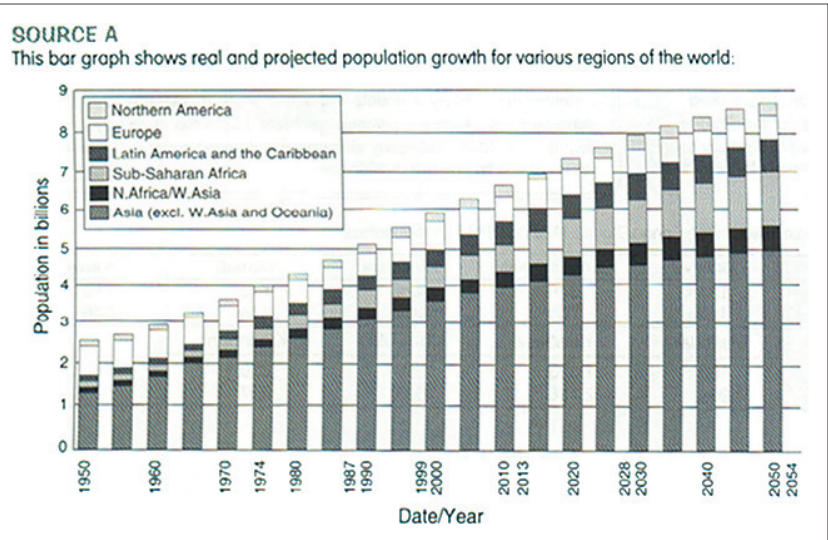

Source: Textbook 1, p. 91

FIGURE 3: A graph revealing a time frame for post-colonial Africa.

Africa. This can be illustrated in the timelines that are summed up in Table 2. Working with the dates in the table, the temporal notion of post-colonial Africa from the visual text can be described to be ranging from 1847 to 2050. This is evidently different from the description of the verbal text which ranged from the 1960s to the present day. Although the latest dates in three of the textbooks are in the 1990s, it can be seen that there is a tendency to construct the post-colonial Africa in a state of temporal perpetuity.

As seen in Table 2, the textbooks have varying time frames for post-colonial Africa. This reveals a complication in the construction of post-colonial Africa because a country such 
TABLE 2: Time frames for post-colonial Africa from the four textbooks (visual text).

\begin{tabular}{ll}
\hline Textbook & Time frame \\
\hline Textbook 1 & $1847-1993$ \\
Textbook 2 & $1960-2050$ \\
Textbook 3 & $1952-1998$ \\
Textbook 4 & $1964-1995$ \\
\hline
\end{tabular}

as Liberia is represented as having been post-colonial before some countries were even colonised. Such a complication lies at the heart of the contestations of post-colonial theory, especially the contestation over identification of the start and end of the post-colonial period (Shohat 1992; St-Pierre 1997; Tosh 2009; Young 2004). The contestation over the postcolonial time marker promotes the construction of a multifarious temporal notion of Africa whereby it is easier to look at specific countries rather than Africa as a single unit.

The visual text also reveals the future projection of postcolonial Africa. Such a positioning is related to the arguments by St-Pierre (1997) and Tosh (2009) on the demise of postcolonial time. Three of the textbooks deal with issues in postcolonial Africa up to the mid-1990s giving an impression that the post-colonial period ended then. The exception is textbook 1 , which features a visual that projects post-colonial issues to 2050, thus constructing a future consciousness for the textbook readers. Shohat (1992) finds this to be ahistorical, because it entails history learners analysing 21st century events within the same historical context as the 1950s.

\section{Post-colonial Africa as fragmented}

There is a contradictory tension in the findings in terms of how the textbooks also acknowledge that the post-colonial condition in Africa has not been consistently uniform, thus representing the post-colonial era in a fragmented manner. As evidence of this fragmentation, textbook 2 (p. 75) lexicalises the 1960 s as 'Africa's "troubled honeymoon"' period meaning that there were other periods of the post-colonial era. Textbook 4 (p. 107) constructs the same 1960s as a period of 'economic progress' in Africa, with the continent falling into 'an economic crisis' in the 1970s. On the same issue, textbook 3 offers a more holistic perspective by characterising the 1960s as a period of 'modest growth,' while the decades that followed were characterised by 'severe economic constraints' (p. 92). These representations reveal a fragmented representation of the actual condition of post-colonial Africa. Although the common representation was that post-colonial Africa continues to the present day, textbook 4 furthers it into the future by mentioning the bright potential that Africa possesses for the future. This shows another case of fragmentation of the post-colonial era.

Nevertheless, the description of findings showed that in spite of the ambiguity in the verbal text, the pattern emerging from the analysis is that post-colonial Africa is constructed to be ranging from the 1960s to the present day. The verbal text shows the 1960s to be a unique period where there was economic growth against great odds. It identifies the 1970s to be the beginning of crises in most of Africa which climaxed in the 1980s, and the 1990s to be marking the beginning of new hope for democracy and growth. This construction shows that post-colonial Africa in the textbooks is also constructed as an assortment of different temporal frames, implying that different parts of Africa have not had the same temporal notion of the post-colonial condition.

\section{Conclusion}

The purpose of this article was to provide an understanding of the representation of the temporal notion of post-colonial Africa as represented in South African history textbooks. The rationale is that it is important for South African history learners and teachers to have a good understanding of the concept of post-colonial, because historical time is one of the key concepts to historical understanding. This is especially so for post-colonial Africa, at a time when the decolonisation movements in South Africa have characterised the country to be post-colonial. The findings described show that although post-colonial Africa is constructed through a temporal notion, it is not clearly framed within a particular period. The ambiguity of the temporal notion, a fundamental concept in history, stems from the fact that lexicalisations used as time markers cannot be linked to one particular date, resulting in a post-colonial Africa whose beginning and - more specificallyend cannot be unambiguously determined. Notwithstanding, the textbooks revealed both generalised and fragmented conceptions of the post-colonial African period.

This study therefore notes with concern the contradictions that are evident in the textbooks with reference to the temporal notion of post-colonial Africa. Much as textbooks should not be purveyors of single narrative propaganda, neither should they be representing conceptual chaos. Instead, there is a need for a stronger conceptualisation of the temporal notion of post-colonial Africa, just as should be the case with other historical concepts in the textbooks. Although textbook analysts cannot necessarily predict the effects of the said textbooks on their users, research has shown that a weak understanding of time has an adverse effect on the understanding of the historical events associated with the particular time (Stow \& Haydn 2012). This may mean that learners of South African history will not be well equipped to understand the contemporary dynamics from a post-colonial perspective.

Another conclusion concerns the use of colonialism as a time marker in African history, which the textbooks do. As McClintock (1993) argues, this approach is problematic as attested by the ambiguities and differences on the meaning of post-colonial Africa across the analysed textbooks. This is why Tosh describes postcolonialism as nothing more than just a convenient, but superficial chronological marker (Tosh 2009). This is in addition to the argument that using colonialism as a significant time marker results in giving colonialism the prominence and prestige that post-colonial textbooks are supposed to counter (McClintock 1993; Shohat 1992). This leaves open an opportunity to consider other possible time markers for African history. 


\section{Acknowledgements Competing interests}

The author declares that he has no financial or personal relationships which may have inappropriately influenced him in writing this article.

\section{References}

Barnard, C., 2003, Language, ideology, and Japanese history textbooks, RoutledgeCurzon, London.

Bartels, J., Dlamini, N., du Rand, S., Ellis, P., Haw, S., Kurumbidza, B. et al., 2006 Shuters history grade 12 learner's book, Shuter \& Shooter, Pietermaritzburg.

Bhabha, H.K., 1994, The location of culture, Routledge, London.

Bottaro, J., Visser, P. \& Worden, N., 2006, Oxford in search of history Grade 12, Oxford University Press, Oxford.

Claire, H., Deftereos, R., Dugmore, C., Ramoroka, D., Van Reenen, V. \& Titus, V., 2007, Making history grade 12, Heinemann, Johannesburg.

Dimitriadis, G. \& Kamberelis, G., 2006, Theory for education, Taylor \& Francis, New York.

Fairclough, N., 1995, Critical discourse analysis, Longman, London.

Fanon, F., 1961, The wretched of the earth, Grove Press, New York.

Firer, R., 1998, 'Human rights in history and civics textbooks: The case of Israel', Curriculum Inquiry 28(2), 195-208. https://doi.org/10.1111/0362-6784.00084

Foster, S. \& Crawford, K., 2006, What shall we tell the children: International perspectives on school history textbooks, Information Age Publishers, Greenwich.

Friedman, M., Kros, C., Mlambo, A., Saundders, C., Seleti, Y. \& Jacobs, M., 2007, Focus on history: Looking into the past Grade 12, Maskew Miller Longman, Cape Town.

Halliday, M.A.K., 1985, An introduction to functional grammar, Edward Arnold, London.

Hitchcock, P., 1997, 'Postcolonial Africa? Problems of theory', Women's Studies Quarterly 25(3/4), 233-244, viewed 23 February 2010, from http://www.jstor. org/stable/4000338

Howarth, D., Norval, A.J. \& Stavrakakis, Y., 2000, 'Introducing discourse theory and political analysis', in D. Howarth, A.J. Norval \& Y. Stavrakakis (eds.), Discourse theory and political analysis: Identities, hegemonies and social change, pp. 1-23, Manchester University Press, Manchester.

Ifversen, J., 2003, 'Text, discourse, concept: Approaches to textual analysis', Kontur 7, 60-69.

Janks, H., 1997, 'Critical discourse analysis as a research tool', Discourse: Studies in the Cultural Politics of Education 18(3), 239-242. https://doi.org/10.1080/ 0159630970180302

Kojanitz, L., 2008, 'Learning-centered quality assessment', Paper presented at the Ninth International Conference on Textbooks and Educational Media: Peace, Democratization and Reconciliation in Textbooks and Educational Media, Tonsberg, Norway, September 2007.

Lebrun, J., Lenoir, Y., Laforest, M., Larose, F., Roy, G., Spallanzani, C. et al., 2002, 'Past and current trends in the analysis of textbooks in a Quebec context', Curriculum Inquiry 32(1), 51-83. https://doi.org/10.1111/1467-873X.00215
Luckett, K., 2016, 'Curriculum contestation in a post-colonial context: A view from the South', Teaching in Higher Education 21(4), 415-428. https://doi.org/10.1080/13 562517.2016.1155547

Mamdani, M., 2011, 'Africa's post-colonial scourge', Mail \& Guardian Online, 27 May, viewed 02 May 2018, from https://mg.co.za/article/2011-05-27-africaspostcolonial-scourge

Maposa, M.T., 2014, 'An analysis of the construction of African consciousness in contemporary South African history textbooks', Unpublished doctoral thesis, University of KwaZulu-Natal, Durban.

Maposa, M.T., 2015, 'Reflections on applying critical discourse analysis methodologies in analysing South African history textbooks', Yesterday \& Today 14, 58-75. https://doi.org/10.17159/2223-0386/2015/nl4a3

Mbembe, A., n.d., Decolonizing knowledge and the question of the archive, viewed 06 October 2016, from https://wiser.wits.ac.za/system/files/Achille\%20Mbembe\% $20-\% 20$ Decolonizing $\% 20$ Knowledge $\% 20$ and $\% 20$ the $\% 20$ Question $\% 20$ of $\% 20$ the $\% 20$ Archive.pdf

McClintock, A., 1993, 'The angel of progress: Pitfalls of the term "Postcolonialism"', in R.J. Patrick Williams \& L. Chrisman (eds.), Colonial discourse and post-colonial theory: A reader, pp. 84-98, Harvester Wheatsheaf, Heme Hempstead.

Naseem, M.A., 2008, 'Texts of war/texts of peace: Dismantling violence and constructing peace in textbooks and educational media', Paper presented at the Ninth International Conference on Textbooks and Educational Media: Peace, Democratization and Reconciliation in Textbooks and Educational Media, Tonsberg, Norway, September 2007.

Nicholls, J., 2003, 'Methods in school textbook research', International Journal of Historical Learning, Teaching and Research 3(2), 11-26.

Pingel, F., 2010, UNESCO guidebook on textbook research and textbook revision, United Nations Educational, Scientific and Cultural Organization/Braunschweig: Georg Eckert Institute for International Textbook Research, Paris.

Rahaman, S., Yeazdani, R. \& Mahmud, R., 2017, 'The untold history of neocolonialism in Africa (1960-2011)', History Research 5(1), 9-16. https://doi.org/10.11648/j. history.20170501.12

Rodden, J., 2009, 'Ideology as core curriculum? Textbooks and German re-education in May 1945,' The Midwest Quarterly 50(3), 267-218.

Said, E., 1978, Orientalism, Vintage Books, New York.

Shohat, E., 1992, 'Notes on the "post-colonial"', Social Text 31/32, 99-113. https://doi. org/10.2307/466220

Spivak, G., 1993, Outside in the teaching machine, Routledge, London.

St-Pierre, P., 1997, 'Multiple meanings and contexts: The diversity of the post-colonial', TTR: Traduction, Terminologie, Redaction 10(1), 9-17, viewed 23 March 2010, from http://id.erudit.org/iderudit/037278ar

Stow, W. \& Haydn, T., 2012, 'Issues in the teaching of chronology', in J. Arthur \& R. Phillips (eds.), Issues in teaching history, pp. 83-97, Routledge, London.

The 1931 Statute of Westminster, 1937, Queensland Government Printer Brisbane.

Tosh, J., 2009, The pursuit of history, Routledge, London.

Van Dijk, T.A., 2003, 'Critical discourse analysis', in D. Schiffrin, D. Tannen \& H.E. Hamilton (eds.), The handbook of discourse analysis, Wiley-Blackwell, viewed 06 October 2010, from http://au.wiley.com/WileyCDA/WileyTitle/productCd-0631205969. html

Young, C., 2004, 'The end of the post-colonial state in Africa? Reflections on changing African political dynamics', African Affairs 103(410), 23-49. https://doi.org/ African political dyna 